\title{
A HATÉKONY TANULÁS TITKA
}

\section{Mikó Magdolna}

a Batthyány Ilona Általános Iskola igazgatója

bugicink@freemail.hu

Az a mü, amit a fenti címmel lehetne egyszerüen jellemezni, Hollandiában jelent meg először, s népszerüségét mi sem mutatja jobban, hogy már a második, tapasztalatokban még gazdagabb magyar kiadást tarthatja kezében az Olvasó. Az első, a Calibra Kiadó gondozásában látott napvilágot, az eredeti, külföldi kiadás után 2 évvel, vagyis 1997-ben. Az egyik szerzö, Paul Roeders társas, csoportos tanulási folyamatokra alapozott, Hollandiában megkezdett és elmélyített kutatásai nem csak Magyarországon lettek ismertek; eredményei bejárták Európát, majd Latin Amerikát, sőt Ázsia és Afrika egyes országait is. Peruban, 1998-ban, a tanárképzési rendszer átalakításában elért sikereiért az Állami Egyetem tiszteletbeli professzorává választották. A társszerző, Gefferth Éva nyelvtanár és pszichológus, a kooperatív tanulás és a tehetséggondozás vezető szakembere, az MTA Pszichológiai Intézetének sokoldalú munkatársa. A Magyar Tehetséggondozó Társaság alapítója, majd elnöke volt. A második magyar kiadás fordításában Damokos Katalinnal, a lektorálásában M. Nádasi Máriával dolgozott együtt.

A kötet a hatékony tanításról és tanulásról, illetve az ehhez vezető utakról és módszerekről szól, elsősorban a közoktatásban dolgozó pedagógusokhoz, iskolaigazgatókhoz, pedagógusképzésben és a felsőoktatásban dolgozó oktatókhoz, de bátran ajánlható módszertani trénereknek is. Az elméleti megközelítést konkrét, gyakorlati tanácsok szövik át, melyek már önmagukban is sokat segíthetnek az iskolai munka hatékonyabbá tételében. Nem csupán „mankót nyújthatnak”, hanem új tanulási módszerek bevezetésére, a tanítási óra átértelmezésére bátorítanak. Továbbá útmutatót adnak a tanulók között mindenütt meglévő, sokféle - képességbeli, mentális, érdeklődési, családi - sokszínűség kezeléséhez. Minden ötlet és példa nemzetközi tapasztalatokra épül; az amerikai és a nyugat-európai elméletek a fejlődő országokban szerzett tapasztalatokkal ötvözve a pedagógiai helyzetek széles skáláját ölelik fel. Mindez már önmagában is saját tapasztalatainak új megközelítésére ösztönözheti az olvasót.

A könyv négy fő részre tagolódik. A további fejezetek, alfejezetek révén mind a négy rész felépítése és gondolatmenete jól áttekinthető, és tanuláskor, tanításkor könnyen felidézhető és felhasználható. A következőkben e négy fő részből, az ismertetés szempontjából leglényegesebb fejezeteket tekintem át; a fejezetek címét dőlt betüvel jelzem. 
Az első rész, melynek címe „Az oktatás újszerü szemlélete” elméleti megalapozás. Mottója egy kínai közmondás: „A tízezer mérföldes utazás is egyetlen lépéssel kezdődik.” Imponálóan gazdag és átfogó anyagot tartalmaz, egymagában több mint száz oldal, tehát közel fele a könyv teljes terjedelmének. Az első rész első fejezete $A$ nevelés és oktatás elsödleges célja címet viseli, s a társas, kooperatív technikák széles skáláját mutatja be. A csoportos tanulás és a tanítás kapcsán újszerủ megközelítéseket alkalmaz, melyek segítik a tanulók egyéni felelősségérzetének kialakítását, kreativitásuk kibontakoztatását. „... a gyerekeket ösztönözni kell, hogy ráébredjenek, felfedezzék, miben tehetségesek, mi tartozik az érdeklődési körükbe" - állapítják meg a szerzők (19. o.). Fontos tehát úgy megszervezni a tanulási órákat, hogy a tanulók saját tapasztalataik révén erősíthessék önmaguk iránt érzett felelösségüket, miközben a tanár is megvalósítja oktatási-nevelési célkitüzéseit. Az oktatás, mint holisztikus folyamat címü fejezet a tudományos rendszerelmélet alapjaira helyezi a hangsúlyt, A tanulás biológiai alapjai az agyi struktúrák fejlettségének és a memória múködésének kapcsolatait elemzi, továbbá azt, hogy mindez - az emlékezet révén - milyen hatást gyakorol a tanulás folyamatára. Például megtudhatjuk, hogy minél kiterjedtebb az információ-összeköttetések hálózata, annál könnyebben lesz később felidézhető a konkrét ismeret. Vagyis: könnyebben megjegyezzük azokat az ismereteket, melyekhez több csatornán keresztül is hozzájuthatunk. A hatékony tanulás legfontosabb alapelvei ebben az összefüggésben is a bizalom légkörén alapuló nyugodt környezet, az aktív tanulás, a mindkét agyfélteke egyenlő terhelése, az emberi bioritmushoz alkalmazkodó tanításszervezés, valamint a feszültségmentes, a támogató légkör. Az oktatás, ami a diákokat útjukon elkíséri és az Egy elöfeltétel: a diákok közötti támogató kapcsolatok, címü fejezetekben a nevelés céljaként a tanulás és fejlődés jelenik meg, az interakciókat hangsúlyozva. A tanulók kortársi kapcsolatokban azonosulhatnak számukra imponáló tulajdonságokkal, szerepekkel, így modellek lehetnek egymás számára. A társas interakciók keretei között az autonóm személyiség megérti, hogy mit várnak tőle egy adott szituációban, $\mathrm{s}$ el tudja dönteni, kíván-e ennek megfelelni. Nem feltétlenül veti alá magát mások döntéseinek, de rugalmasan figyelembe veszi saját és mások értékrendjét, és ennek megfelelően cselekszik. A szerzők utalnak Guldemond (1994) állítására, mely szerint egy tanuló eredményét jobban befolyásolja szociális támogatottsága, mint az adott csoport, tanuláshoz való viszonya. Ezt továbbfüzve Roeders szerint végzetes következménye lehet egy személy társadalmi sikerességének, ha valakiböl hiányzik a készség a másokkal történő együttmüködésre egy adott cél érdekében. Eredményei szerint a támogató kooperatív tanulási csoportokban nagyobb a tanulási motiváció, mint más oktatási formákban. „Sok iskolában, vállalatnál vagy családban lényegesen kevesebb volna a probléma, ha olyan embereket lehetne találni, akik képesek a másikat támogatni." (61. o.) A Kinek felel meg a diákokat kísérö oktatás című fejezet, a szerzők kutatási eredményeinek kooperatív tanulásra gyakorolt hatását ismerteti. Ezt a hatást már a hazai szakirodalomban is többen vizsgálták, elemezték (Benda, 
1994, 2002; M. Nádasi, 2003; Vastagh, 1996, 1999; Horváth, 1994). Paul Roeders hivatkozik saját 1986-ban írt müvére is. Megállapításai a következők:

1. az együttmüködő tanulás elősegíti a kognitív képességek fejlődését;

2. a különböző vélemények, viták a tanultak alaposabb megértéséhez vezetnek;

3. az interaktív feladatmegoldás könnyíti a tanulást;

4. heterogén csoportok a leghatékonyabbak;

5. a homogén csoportok a felfedező tanulásnál alkalmazhatók jól.

A diákokat kísérő oktatás végső célja a diákok képességeinek legszélesebb körü kibontakoztatása. Ehhez kis létszámú tanulócsoportok szükségesek, akár az osztály adott keretein belül is. A következö fejezet címe Az intellektuális fejlödés és a többszörös intelligencia. Lényege az oktatás általános célrendszerének, a tanuló személyiségfejlesztésének, az interiorizáció folyamatának elemzése. A szerzők felhívják a figyelmet: cél elérésének szükséges feltétele, hogy a tanár felismerje tanítványai intelligenciastruktúráját, melyek szerintük a következő nyolc formában kap kiemelt szerepet:

1. nyelvi intelligencia;

2. zenei intelligencia;

3. logikai-matematikai intelligencia;

4. téri-vizuális intelligencia;

5. testi-kinesztetikus intelligencia;

6. intraperszonális- személyes intelligencia;

7. interperszonális- személyek közötti intelligencia;

8. természeti (1999) intelligencia.

A társas és erkölcsi fogalmak: az oktatási tevékenységek legitimációjának alapja címü fejezet a társas valóságra vonatkozó nézeteket tárja fel. Az első rész utolsó fejezete a tanulók baráti kapcsolatairól szól. A szerzők tanúságot tesznek a jó barátság fontossága mellett. A kölcsönös bizalom nem csupán a tanulók egyéni szempontjából fontos, hanem az osztály légkörét is jelentősen javítja, és sokkal inkább serkenti az ismeretek megértését, mint a versengés vagy a megfélemlítés. Ráadásul az iskolai barátságok jó eséllyel maradnak fenn egész életen át.

A második rész szervezeti és gyakorlati szempontokra épül, $\mathrm{s}$ ezt már a cím is elárulja: A változó iskolaszervezet. Mottója „A tanulás az egyik legértékesebb adomány, mert képessé tesz felfogásod megváltoztatására." (99. o.) Fejezetei az iskola, az osztályszervezeti felépítését és a csoportos munkaformák előfeltételeit tárgyalják. Az iskola szervezése és a kooperatív módszerek bevezetése címü fejezetben a csoportmunka szervezésének folyamatát és színtereit ismerteti az alábbi elv szerint:

1. hozzászoktatás, kezdő gyakorlat két-három tanulóval egy-egy feladat elvégzésére;

2. gyakorlás útján való elsajátítás - szabályok, sémák begyakoroltatása;

3. közbelépés-intézkedés - csoportkohézió lazulása esetén egy-egy tanári tanács, segítség. 
Vagyis már a kezdetektől látható, hogy a tanár szerepe megváltozott. Fő feladata nem az utasítás, magyarázat vagy előadás, hanem rugalmas segítség, háttérből történő tanácsadás, szervezés. A csoport nagyságának kiválasztásakor a módszertani, didaktikai meggondolásokon kívül célszerü érzelmi tényezőket is figyelembe venni. A csoport összetételét tekintve pedig új anyag feldolgozására inkább a heterogén szervezés alkalmasabb. Hiszen az ügyesebbek, tájékozottabbak szívesen tanítják meg a többieknek, amit tudnak, a gyengébbek pedig szívesen tanulnak újat társaiktól, ráadásul ez témánként, tantárgyanként még változik is. Egyik tanuló az egyik dolgot tudja jobban, míg társa egy másikat. Azonban ügyelni kell arra, hogy a csoport minden tagja megtalálhassa azt a feladatot, amiben ö a ténylegesen jobb. A csoport fejlődésének sorrendjét a szerzők metafora segítségével mutatják be. A gyökerekből növő fatörzs a tandemet, a tanulópárt szimbolizálják. A vastag ágak a diákcsoportot, az ellentmondásokat és a vitákat jelképezik. Végül a fa koronája már az egész csoportos projektet. Ehhez a munkához korszerü iskola szükséges. Elegendő tér, fény, könnyen mozgatható bútorok a tanterem gyakori átrendezéséhez. Jó hangulatot kell, hogy árasszon, mely a gyerekek és szülők számára egyaránt vonzerőt jelenthet. Konkrét példákat, alaprajzokat láthatunk a tanterem lehetséges elrendezésére (például harminckét fős létszám mellett a nyolc négyes csoport praktikus elrendezéséhez). Természetesen a tanár felelősségérről és feladatairól is szó esik. A tanulási folyamatok sikerességének záloga pedig az iskola keretein belül jól együttmüködő tanári team. A másik fejezet címe a Diákokat kísérő oktatás és az iskola szervezete, mely a csoportos oktatás tervezését és alkalmazhatóságát elemzi. A szerzők a hazai szakirodalomra hivatkoznak, melyek a csoportos és a kooperatív oktatás előnyeiröl, illetve hasznosságáról szólnak. Horváth Attila a kooperatív technikákról írt Kooperativ technikák. Hatékonyság a nevelésben címmel 1994-ben, az Új Pedagógiai Szemlében Benda József 2002-ben a kooperatív pedagógia szocializációs sikereiről és lehetőségeiről. Ugyanerről a témáról Vastagh Zoltánnak több kötete is jelent meg a Janus Pannonius Tudományegyetem gondozásában, még az 1990-es évek második felében. Differenciált fejlesztés - kooperatív tanulás címmel pedig Hunyady Györgyné szerkesztett jegyzetet az ELTE Tanító- és Óvóképzős hallgatói számára, 2003-ban. Azonban, Paul Roeders és Gefferth Éva könyve túlmutat a szakirodalom alapvető állásfoglalásain, mert az önirányító tanulás és csoportos szervezési forma egész iskolára való kiterjesztése mellett érvel. „Több esetet is ismerünk, ahol a kisebb körben beindult sikeres alkalmazás kiterjedt az egész iskolára ... míg végül az egész tanári kar úgy döntött, hogy az iskola szinten vállalják a tanulásszervezés megváltoztatását." (123. o.) A szerzők hangsúlyozzák, hogy a kritikus pont a tervezés. A hagyományos osztály önirányító iskolai osztállyá fejlődésének leghatékonyabb módja a szisztematikus végrehajtás. A hierarchikus összefüggéseket is feltáró gondolattérkép megszerkesztése segítheti a tervezést és a stratégia kialakítását. A tevékenységeket stratégiai tervezésekor meg kell határozni a szükséges idöt is. A szükséges forrásokat is fel kell térképeznünk, melyekre majd 
építeni akarunk. Fullan (1990) gondolatait és a tanári team munkát újraértelmezve, peer management-ként definiálva, az iskola nyitottsága mellett érvelnek a szerzők: „Az aktív részvétel a döntéshozatalban, (...) fokozza a szervezet hatékonyságát és a team tagjainak elégedettségét." (129. o.)

A harmadik rész gyakorlati munkamódszerekre ad példákat „a tanítás, tanulás, így tanárból tanuló, és a tanulóból tanár lesz." Fogalmazza meg mottójában Roeders. Nagyon konkrét, a gyakorlatban közvetlenül használható csoportos módszereket ismertet, azok jellemzőivel, előnyeivel és alkalmazásai lehetőségeivel együtt, számos gyakorlati tanáccsal. Ez a rész jelentős segítséget nyújt az órára készülő pedagógus számára. Közben, az önirányítás módszereit, szervezési formáit, még mintafeladatokat is bemutat. Az első három rész, feladatokkal zárul. Ezek megoldása, végiggondolása egyrészt segíti az Olvasót az alaposabb megértésben és az önellenőrzésben, másrészt útmutatásul szolgálhat az olvasottak kipróbálásakor is. A kérdések, feladatok olyan kritikus pontokra világítanak rá, melyek kiküszöbölésével a pedagógusok sikeresebben végezhetik munkájukat.

A könyv utolsó része, melynek címe Gyakorlati tapasztalatok, egy kísérlet eredményeiről számol be. „Aki kérdez, tévedhet. Aki sohasem kérdez, folyamatosan téved" - hangsúlyozza a mottó. Egy hollandiai kísérleti iskola három osztályában már bevezették a könyvben ismertetett újításokat. Az eredményeket három kontroll-osztállyal összevetve azt tapasztalták, hogy a kísérleti iskola tanulói jobb iskolai elömenetelt mutatnak, tanulási és közösségi beilleszkedési problémáik csökkentek. Ráadásul a kísérleti iskola tanárai elégedettebbek voltak, és motiváltnak mutatkoztak a kísérlet folytatására. Az önirányítással tanuló csoportokat három általános iskola hatodik, hetedik és nyolcadik évfolyamán vizsgálták. Az osztályok tanulóinak összlétszáma 154 fő volt, ebből 82 lány és 72 fiú. A gyerekek előzetes felmérőt írtak, még a kísérlet bevezetése elött, majd a befejezést követő héten egy záró tesztet, kilenc héttel később pedig egy utótesztet is. Az eredmények összehasonlíthatósága érdekében e dolgozatokat három, hagyományos módszerrel dolgozó kontroll-iskolában is megíratták, ahol a 215 tanuló véletlenszerü kiválasztása a kísérletben szereplökkel azonos évfolyamokból történt. Az önirányító tanulói csoportokban történő oktatás bevezetését hat tájékoztató értekezlet előzte meg. Ezeken a program elméleti hátterét, a kiscsoportos oktatás öt fajtáját ismerhették meg a pedagógusok, szemléltetésekkel, gyakorlatokkal kiegészítve. Az alkalmazás összesen tizenöt hétig tartott. Mindvégig együttmüködő tanári csoportok dolgoztak, folyamatosan egyeztetve. A kísérlet hatását kovariációs elemzéssel végezték (az előzetes felmérést használták kovariánsnak). Az önirányító csoportokban dolgozó diákok matematikából és szövegértésből jobb eredményt értek el, mint a kontroll-iskolában. A különbség a záró- és utótesztben egyaránt szignifikáns volt. Az önirányító tanulók tanulási motivációja és önértékelése egyaránt fokozódott. Az osztály légköre is kedvezőbbé vált. A kísérlet nem minden területen mutatott kedvezőbb képet a hagyományosnál, de egyetlen területen sem járt kedvezőtlen hatással. Végső kö- 
vetkeztetésként a szerzők rámutatnak arra, hogy bár a kutatások, kísérletek a különböző kooperatív csoport technikák alkalmazásában különbségeket mutatnak, ugyanakkor kivétel nélkül megegyeznek abban, hogy szignifikánsan jobb eredményhez vezetnek, mint a hagyományos pedagógiai eljárások.

Összegezve: Paul Roeders és Gefferth Éva kötetét minden újításra nyitott, és a hatékony pedagógiai munka lehetséges útjait kereső kollégám számára ajánlom. Tartalmi gazdagsága mellett felhívnám a figyelmet az igényes kivitelezésre, a gazdag ábraanyagra, a rendkívül színvonalas és igényes, színes illusztrációkra. Elméleti ismeretekkel és gyakorlati útmutatásokkal, ötletekkel egyaránt gazdagít minden olvasót, sőt, lelkierőt ad ezek kipróbálásához is. Végül a szerzők szavait idézem. „Azt reméljük, hogy ez a kézikönyv az iskola, de elsősorban a tanár erőfeszítései révén hozzájárulhat ahhoz, hogy mind a tanárok, mind a diákok kellemesebben érezzék magukat az iskolában, és ezáltal mindkét fél számára hatékonyabbá váljék az oktatás." (16. o.)

Roeders, Paul és Gefferth Éva (2007): A hatékony tanitás és tanulás dinamikája. Trefort Kiadó, Budapest, 215 oldal.

\section{Irodalom}

Benda József (1994): A HKT program hatásvizsgálata. Humanisztikus Iskola Alapítvány, Budapest.

Benda József (2002): A kooperatív pedagógia szocializációs sikerei és lehetőségei Magyarországon I-II. Új Pedagógiai Szemle, 9. sz. 26-37. és 10. sz. 21-33.

Fullan, M. (1990): Staff development, innovation and institutional development. In: Wyner, N. (ed.): Current perspectives ont he culture of schools. Brookline Books. 113-135.

Horváth Attila (1994): Kooperatív technikák. Hatékonyság a nevelésben. Budapest, IFA. http://www.hkt2000.hu/kpm/horvatha/ha.html

Hunyady Györgyné (2003): Differenciált fejlesztés - kooperativ tanulás. ELTE Tanító- és Óvóképző Főiskolai Kar, Budapest.

M. Nádasi Mária (2003): Projektoktatás. Gondolat Kiadói Kör, Budapest.

Vastagh Zoltán (1995): Iskolafejlesztő törekvések, kooperatív pedagógiai stratégiák. In: Vastagh Zoltán (szerk.): Kooperatív pedagógiai stratégiák az iskolában I. JPTE Tanátképzö Intézete, Pécs. 3-7.

Vastagh Zoltán (1996): Iskolafejlesztés, kooperatív pedagógiai stratégiák. In: Vastagh Zoltán (szerk.): Kooperatív pedagógiai stratégiák az iskolában II. JPTE Tanárképző Intézete, Pécs. 3-7.

Vastagh Zoltán (1999): Az iskolai oktatás hatékonyságát növelö kooperatív, kiscsoportos tanulás. In: Vastagh Zoltán (szerk.): Kooperatív pedagógiai stratégiák az iskolában III. JPTE Tanátképző Intézete, Pécs. 25-31. 